\title{
Horizonte cristiano de la pastoral de la movilidad*
}

\author{
Pedro Trigo, \\ Centro Gumilla, \\ Caracas
}

Como el cristianismo se presenta como la salvación y plenificación de la realidad histórica, no podemos referirnos al horizonte cristiano de la movilidad humana sin comenzar presentando, aunque sea sucintamente, la movilidad humana, tal como actualmente se da, para hacer ver en un segundo momento cómo ese horizonte trascendente da sentido, salva y plenifica a esta realidad, tal como reluce en nuestra situación. No se trata de aportar estudios científicos sino de caracterizar este fenómeno desde una mirada cristiana. Sin aislarla del resto, enfocaremos nuestra atención a nuestra región latinoamericana.

\section{Discernimiento cristiano de la movilidad actual}

\section{Movilidad humana cuando comienza la historia universal}

De entrada tenemos que decir que no podemos referirnos a la realidad latinoamericana sin aludir a la situación mundial porque estamos llegando a la historia universal, sin que se cancelen por eso las historias locales, regionales, nacionales y de ámbitos culturales más amplios, como es América Latina.

Estamos llegando a la historia universal, no solo porque por los medios electrónicos todo el mundo esté en presencia de todo el mundo sino, lo que es más decisivo, por la comunicación efectiva de unos con otros, incluso por su imbricación estructural, de manera que las historias particulares están confluyendo ante nuestros ojos en una sola historia universal, de la que, queramos o no y para bien o para mal, todos participamos. Participamos tan íntimamente que ya el destino de la humanidad es un destino común.

\footnotetext{
* El texto fue preparado como ponencia para el I Congreso de Pastorales de Movilidad Humana, que tuvo lugar en Panamá del 12 al 16 de mayo.
} 
Hemos afirmado que estamos llegando a la historia universal, pero aún no hemos llegado, porque, aunque ya todos estemos virtualmente en presencia de todos y las comunicaciones y los capitales y las mercancías y las corporaciones y sus gerentes y altos empleados y los turistas no encuentren barreras y se muevan por cualquier lugar como en su casa (lo que es literalmente cierto en el caso de los gerentes y los turistas de lujo porque ese tipo de hoteles son iguales en todo el mundo), los de abajo se topan con barreras inflexibles y, sin embargo, como son imprescindibles para hacer lo que los del lugar no quieren hacer, son recibidos por la puerta falsa, sin papeles de residencia, sin derechos, sin reconocimiento, a merced de las mafias, inseguros siempre, invisibles, solo tolerados, pero activamente explotados. Y todo esto, permitiéndolo burda o descaradamente los gobiernos, incluso los que dicen fundarse en la justicia y el derecho.

Esta situación pone en evidencia que no hemos llegado a la historia universal porque, aunque el ámbito de los que dominan sea ya todo el mundo, el sujeto de esta historia no somos todos los habitantes del planeta sino únicamente los de arriba. Más en concreto, el sujeto de esta historia que comprende a todos los habitantes de la tierra son las corporaciones mundializadas y, sobre todo, los grandes inversionistas y las grandes potencias y, como aliados subordinados, las clases dominantes de los países del tercer mundo, pero no el resto de los moradores de la tierra, incluso de los que viven en los países ricos.

Por eso, aunque formalmente la mayoría de los países viven en democracia, no se puede decir que haya democracia en ningún país del mundo porque los gobernantes no representan a las mayorías sino que, por el contrario, cargan sobre ellas el costo del sistema y más concretamente de las crisis que, como es abiertamente el caso de la presente, provocan exclusivamente los de arriba. Estas élites y los políticos pretendidamente democráticos son los que impiden activamente que pasemos a la historia universal.

Ya en 1968 acusaba el documento de Medellín al "imperialismo internacional del dinero" como principal culpable de la "dictadura económica" $(2,9)$. Hoy, en vez de haberse caminado en la dirección de la genuina democracia, esta dictadura ha llegado a un verdadero totalitarismo. Hoy los grandes, que son una ínfima minoría, someten a las mayorías por el miedo, que es el sentimiento dominante en el mundo y que es activamente inoculado por los de arriba, una actitud anímica incompatible con la genuina democracia.

La actitud de fe-confianza, que solo puede darse a Dios y, desde el Espíritu de Dios, a los seres humanos, hoy la exigen los mercados, es decir, los que los controlan discrecionalmente. Y para que los mercados recobren la confianza (esa es la palabra sagrada que se utiliza), los líderes sacrifican a las grandes mayorías, precarizando el empleo, los sueldos, la estabilidad laboral, la educación, la salud, la seguridad social y hasta el equilibrio ecológico, y eximiéndose ellos hasta de los impuestos más elementales. La irresponsabilidad de los que mandan 
despóticamente no solo lleva a que las mayorías vivan una vida sumamente precaria y mueran antes de tiempo sino, si se persiste en esta dirección, al suicidio colectivo.

Ellos son los principales culpables de que no entremos, como Dios, sin duda, lo quiere y el tiempo histórico lo demanda, en la historia universal. Pero, como también reconocía Medellín, también son "responsables de la injusticia, todos los que no actúan en favor de la justicia con los medios de que disponen, y permanecen pasivos por temor a los sacrificios y a los riesgos personales que implica toda acción audaz y verdaderamente eficaz" $(2,18)$. Ello es así porque el derecho de ser sujeto histórico tiene que conquistarse, justa y pacíficamente, pero ineludiblemente tiene que ejercerse, haciéndose un lugar, el que ellos, injusta e irracionalmente, no quieren dar.

Este preámbulo era indispensable porque es distinto hablar de la movilidad humana en un tiempo de historias particulares más o menos en contacto, que cuando se está entrando en la historia universal, cuando ya se ha entrado en las magnitudes objetivas, es decir, en las mercancías y en los que comandan la economía y en sus organizaciones; pero cuando, por la resistencia injusta e irracional de esas élites, no todos somos sujetos de esta historia que ya nos abarca a todos, porque todos participamos más o menos de ella y todos la padecemos.

\section{Las migraciones del campo a la ciudad, matriz de las migraciones a otros países de la zona y al primer mundo}

Hoy en nuestra América los grandes protagonistas de la movilidad humana son los migrantes. Ante todo tenemos que referirnos a unos migrantes invisibilizados, pero que son los protagonistas indiscutibles de una gesta histórica que será vista en el futuro con un inmenso respeto y celebrada por su extremada creatividad y heroísmo, en medio de condiciones muy adversas. Son las migraciones de los campesinos a las ciudades, sobre todo en las primeras décadas de la segunda mitad del siglo pasado, que han revolucionado el mapa humano que se había gestado en estos quinientos años en América Latina y han posibilitado el desarrollo y lo siguen haciendo.

No los recibieron, ni los ciudadanos ni los gobiernos, fueron hostilizados por la policía; pero se establecieron por su cuenta, aprendieron oficios especializados $\mathrm{y}$, con la alianza, en el mejor de los casos, de profesionales solidarios, fueron los artífices del paso de la sociedad señorial de antaño a la sociedad moderna democrática o, como dice Medellín, de unas condiciones de vida menos humanas a otras más humanas, con las especificaciones tan pertinentes, que presenta el documento, siguiendo a la Populorum Progressio (Int. 6).

Sin embargo, esa transformación no se ha completado todavía porque fue férreamente resistida por los de arriba que no vacilaron en aliarse con los 
militares e instaurar regímenes de Seguridad Nacional, que, en realidad, fueron de resistencia injusta y retrógrada a una movilidad social y económica dinamizadora. En otros casos, la dominación de las élites tradicionales era tan completa que bastaron las democracias meramente formales, en las que, con otra fachada, seguía todo como antes.

\section{La migración a otros países de la región y al primer mundo}

Esa misma dinámica llevó a emigrar de un país a otro; muchas veces, por causa de esas dictaduras totalitarias o de ese totalitarismo de los de siempre con fachada democrática. En los países de acogida, de entrada, los migrantes fueron los más pobres de entre los pobres; pero ese dinamismo que los había llevado fuera de sus países obró como palanca que les hizo labrarse una mínima estabilidad y a la larga una posición mejor que la de partida y de no pocos del lugar de acogida.

De ahí vino el aumento exponencial de las migraciones a los países del primer mundo, en especial a Estados Unidos y Europa, principalmente España por la afinidad idiomática.

Mientras la economía de esos países crecía, muchas veces irresponsablemente, sin querer hacerse cargo de la falta de bases o de su fragilidad, los emigrantes eran bienvenidos porque existía la percepción de que había lugar para todos y porque realizaban oficios que los ciudadanos de esos países no querían desempeñar. Pero cuando, como de repente, estalló la crisis que nadie quería ver y que venía incubándose de tiempo atrás, se los empezó a ver como competidores por los bienes y servicios escasos, se discutieron y luego se negaron sus derechos y se los señaló como los culpables del mal ambiente y de la violencia creciente y se los hostilizó. Al fin se empezó a presionar fuertemente para que salieran.

Aunque esta es la situación establecida, en ningún país faltan aliados que individualmente $\mathrm{y}$, sobre todo, asociados, han tratado de contrarrestar ese ambiente entablando relaciones horizontales con ellos, acogiéndolos y dándoles apoyo humano y económico y defensa legal. Hay que resaltar que no pocos de ellos lo hacen por su espíritu cristiano, con calor humano, tenacidad y alegría. Estas minorías solidarias, extremadamente activas, están logrando contrarrestar hasta cierto punto esa matriz de opinión adversa y empiezan a presionar para que ceda la cerrazón estructural, el blindaje legal y afectivo respecto de los emigrantes.

Pero tampoco se puede ocultar que la institución eclesiástica establecida lo más que ha hecho es protestas rituales, meras declaraciones de principio sin efectos tangibles, y así mismo han procedido los cristianos del estatus. Esto hace ver que el establecimiento cristiano forma parte del problema y no de la solución; aunque los cristianos que dan rienda suelta al fermento evangélico, que, aunque 
son minoría, tienen una alta significatividad, sí son conscientes del problema y lo afrontan como parte ineludible de su compromiso cristiano. Lo que significa, de paso, que este problema es muy sintomático respecto del estado del cristianismo en el mundo y particularmente de nuestro cristianismo latinoamericano.

\section{La realidad actual de la movilidad humana expresa en toda su crudeza, magnitud y dureza el pecado del mundo}

Este recorrido tan somero nos hace ver que el problema de la movilidad humana no es un problema tangencial sino que expresa el nudo en el que estamos atrapados, de tal modo que, si no lo resolvemos, no acabaremos por entrar en la historia universal porque los de arriba se niegan a que los de abajo, que son la inmensa mayoría, sean sujetos activos y responsables de ella y no solo los consumidores de sus productos y los productores en condiciones de semiesclavitud, sin ningún derecho, mientras que ellos se arrogan todos.

El problema que no queremos plantear en toda su crudeza, y, más en concreto, el que no quiere plantearse el establecimiento económico, social y político y sus intelectuales orgánicos, y, de una manera particular, el que no quiere plantearse el cristianismo establecido, es que el actual modelo de desarrollo no es universalizable, y, por eso, los que lo comandan y los que se aprovechan de él tienen que mantener a todos los demás seres humanos, que son la abrumadora mayoría de la humanidad, en condiciones de subordinados no deliberantes y de cantidad prescindible, a los que se deja morir de mengua y enfermedades de pobres.

Es claro que si se acometiera resueltamente el problema del desarrollo de África y del resto del tercer mundo y de los cuartos mundos del primer mundo, la movilidad humana tendría un sentido completamente distinto del actual. Tendría el sentido que tiene actualmente la de los que realizan estudios o trabajos especializados, la de los grandes y medianos emprendedores económicos y artísticos y la del personal del trasporte aéreo y los hombres del mar.

\section{La movilidad actual expresa, más todavía, las virtualidades de los de abajo, imprescindibles para una historia realmente humana}

Pero donde abunda el pecado, sobreabunda la gracia. Es cierto que las migraciones de los campesinos evidencian una falta de oportunidades y de servicios y unas relaciones de producción y sociales insoportables; pero no lo es menos que sin una fuerte conciencia de sí, de su dignidad y de sus posibilidades no se habrían despegado de su terruño ni se habrían lanzado a la aventura. Es cierto que sin una capacidad impresionante de aprender en todos los aspectos, de sentido de la oportunidad, de capacidad de abrirse a lo nuevo y de relacionarse con distintos, de confianza en sí mismos y de tenacidad, no habrían podido entrar, resistir y avanzar en un medio tan adverso. 
Y no se puede negar que el establecimiento y sus intelectuales no habían atisbado ese enorme potencial sino que, por el contrario, daban como un hecho incontrastable que los campesinos eran una masa rutinaria, responsable en buena medida del atraso de la región. No los miraban con buenos ojos. La mayoría ni siquiera los miraba y, en general, nadie les preguntaba nada porque se partía del supuesto de que no tenían nada que decir.

Quedó patente que era un establecimiento prejuiciado; una dominación infecunda; del que formaba parte, en buena medida, la institución eclesiástica establecida (no la que se expresó con gran creatividad y fecundidad en Medellín y Puebla y, en parte, sigue viva), para la que los campesinos eran una masa dócil, pero ignorante y supersticiosa, a la que no se podía sacar de su rutina. Así justificaban una relación vertical y unidireccional, claramente antievangélica.

Hay que reconocer que en una aventura tan extrema, no pocos migrantes perdieron el alma, apostando todo al logro; pero la mayoría aspiró al avance con congruencia personal, en todos los aspectos de la existencia, y, poco a poco, lo fue logrando. Y así no solo se cualificó, sino que se hizo mejor.

Lo mismo y más sigue sucediendo hoy. El que en medio de tantos desprecios, cansancio y penalidades, la mayoría sigan apostando por su familia y sacrificándose por ella, teniéndola presente y enviando aquello de lo que ellos se privan, de tal manera que en no pocos países las remesas de los emigrantes constituyan un porcentaje muy considerable del dinero que se mueve; el que donde viven consigan relaciones con las que compartir a fondo; el que, mientras trabajan en condiciones difíciles cultiven su corazón y su religión, de tal modo que los latinoamericanos constituyan en no pocos lugares del primer mundo, por ejemplo en Estados Unidos, la mayoría de lo que se mueve creativamente en esas iglesias, habla muy alto de su capacidad de sacar bienes de males y de convertir la negatividad en oportunidad de crecer en todos los aspectos.

De esta manera la migración no solo patentiza el pecado del mundo, el pecado que la sociedad está llamada a superar, si queremos ser un mundo humano, sino también pone en evidencia la capacidad de acción humanizadora en situaciones muy difíciles, es decir, la capacidad para vivir humanamente en cualquier situación, la posibilidad de ser en ella sujeto de su propia vida y de enrumbarla, no solo hacia una cualificación siempre mayor, sino, más todavía, hacia mayor calidad humana.

De tal modo que no se hace justicia al fenómeno de la migración si se lo ve solo como una injusticia palmaria. Si tenemos el Espíritu de Jesucristo, tenemos que tener ojos para ver tanto heroísmo humano, para alegrarnos de él y para beber de esa fuente de humanidad.

Esta positividad tiene tal calibre que desconocerla es privarse de una palanca imprescindible para un desarrollo alternativo o para pergeñar y llevar a cabo una 
alternativa al desarrollo que se ha mostrado incompatible con la preservación del equilibrio ecológico y con el establecimiento de una sociedad fraterna, sin exclusiones, que es claramente la voluntad del Dios y Padre de nuestro Señor Jesucristo.

\section{La dialéctica del Evangelio no es la dialéctica positiva, sino la dialéctica negativa}

Porque la dialéctica del Evangelio no es la del Occidente, la dialéctica que va de lo positivo a lo más positivo, una dialéctica aristocrática que provoca, ciertamente, un gran dinamismo, pero que lleva inexorablemente a la marginación e incluso al sacrificio de las mayorías en aras del bienestar ilimitado de los de arriba, sino la dialéctica que parte de rehabilitar, sanar, desalienar y plenificar todo lo tenido por el establecimiento como negativo. Para decirlo sin ambages, el Evangelio es para los pobres, para ellos es el Reino, a ellos, los insignificantes, ha tenido a bien el Padre revelar los secretos del Reino y no a los sabios y entendidos. Por eso la suerte eterna pende de lo que hayamos hecho o dejado de hacer con los necesitados.

Los pobres son el único camino de universalidad real. Solo cuando les vaya bien a los pobres les irá bien a todos. Los pobres son el único camino de revelación del Dios cristiano. Solo cuando los pobres reinen y no el dios dinero, reinará Dios en la humanidad; y, correspondientemente, solo cuando reine el Dios y Padre de nuestro Señor Jesucristo y no otro dios, y no el dios dinero, reinarán los pobres.

La universalidad cristiana, que es irrenunciable, pasa por los pobres. No pasa por una nación privilegiada ni por una institución sacralizada. Pasa por los pobres. De eso es sacramento la Iglesia; es decir, ella ha recibido esa revelación y se consagra a su servicio. Por eso los pobres que han recibido esta revelación y viven a partir de ella, los pobres con espíritu, constituyen el corazón de la Iglesia y su jerarquía espiritual.

Porque la dialéctica cristiana no es la dialéctica positiva, que trata de hacer mejores a los buenos, sino la dialéctica negativa, que busca salvar lo que se había perdido, y, al hacerlo, logra la salvación de todos.

Este es el encuadre cristiano para comprender y procesar el problema de las migraciones, tal como hoy se presenta.

\section{Horizonte cristiano de la movilidad actual}

El horizonte cristiano de la movilidad humana se mueve entre dos referencias fundamentales, aunque de diferente peso. La primera es la polaridad entre la tendencia y el derecho a la movilidad, y el sentido de pertenencia y el gusto de habitar en la querencia. La segunda referencia o el segundo nivel, el decisivo, 
cristianamente hablando, se mueve entre la tendencia a la satisfacción de las pulsiones, los deseos y el amor propio, y la aspiración a vivir en la relación personalizadora que saca cada vez más de sí y de lo suyo y que no tiene límite.

\subsection{Tendencia a la movilidad y sentido de pertenencia}

La primera formulación de esas referencias en tensión y la más inmediata es el derecho a moverse en la tierra, que es indivisamente de todos los seres humanos, y, por tanto, el derecho a ejercer la ciudadanía cosmopolita, y, como el otro polo, la tendencia a una querencia, a una tierra y a un pueblo que se sientan como propios.

\section{Búsqueda de una querencia y gusto de sentirse en ella}

Partamos de esta última tendencia que ha predominado hasta ayer mismo como anhelo, no pocas veces insatisfecho, pero profundamente sentido, de la mayor parte de la humanidad. Cada quien nace y se levanta en un determinado territorio humano y frecuentemente lo siente tan suyo que tiende a definirse por él. Parece muy positivo que viva dentro de una determinada cultura y que se esfuerce en aportar lo que esté en su mano para que sea cauce de humanización.

Pongamos un ejemplo ilustrativo. Gran parte de la sierra peruana posee un hábitat muy inclemente. Sin embargo, a través de muchas generaciones, las comunidades indígenas, construyendo acequias y terrazas de cultivo, lograron hacerlo productivo y habitable. Por eso, muchas de esas comunidades, cuando a partir de los años setenta del siglo XVI fueron obligadas a dejar su lugar para reducirse a pueblos, pusieron una resistencia muy tenaz y, en cuanto pudieron, regresaron a su terruño ya que se sentían hijos de esa tierra y de esa comunidad ancestrales que habían posibilitado su existencia, no solo física sino cultural.

Esa ligazón entrañable, incluso sentida como sagrada, a esa tierra y a esa comunidad, tan íntima que los definía como hijos de esos elementos y de esos antepasados de los que provenían, la heredaron los campesinos, sobre todo, los que vivían en comunidades, no tanto los peones de hacienda, y no se puede desechar, sin más, como alienación. El binomio tierra-comunidad contiene una verdadera trascendencia respecto de cada individuo, que no habría podido, no solo vivir sino incluso concebirse, sin esas referencias constituyentes. Por eso, venerar a esa tierra y a esos antepasados no es un acto de idolatría sino un acto de agradecimiento que hace justicia a lo que ha posibilitado su existencia, una existencia trabajada, sufrida y gozada también en las fiestas de comunión con ellos. Así lo supieron ver ya en su tiempo Blas de Valera y el Inca Garcilaso, no por casualidad dos mestizos de altura, en contra de la opinión de la mayoría.

Esto es también lo que está detrás de ese salmo 128 que proclama dichoso, como bendecido de Dios, a aquel que puede vivir del trabajo de sus manos, no 
como mero individuo, sino con su mujer y sus hijos, gozando desde su querencia de la prosperidad de Jerusalén y llegando a ver a los hijos de sus hijos. Después de tantos siglos de trashumancia, de andar errantes en tierras que no eran suyas, ese modo de existir estable y a la vez fecundo era visto como llegar por fin al llegadero al que aspiraron sin conseguirlo tantos antepasados.

¡Cuántos habitantes de barrio se pasan la vida entera levantando su casita y dotándola mínimamente, para lo cual requieren encontrar un trabajo especializado y bien remunerado, y no pocos de ellos llegan a viejos sin haber logrado esa estabilidad básica! Actualmente para muchos de nuestro pueblo llegar a tener algo propio y medio digno, establemente poseído, es un bien tan sobre sus posibilidades que ya casi han dejado de soñar con alcanzarlo.

\section{Si la pertenencia nos define, no somos personas}

No cabe duda de que llegar a tener un rincón propio medio confortable es humano, y luchar denodadamente por conseguirlo humaniza. Pero si, por otra parte, el individuo, que es, indudablemente, de una tierra y una cultura, se define por esa tierra y esa cultura, se define como un elemento de ese conjunto y, por tanto, ya no puede definirse como persona, ya que la persona es tal cuando se acepta, no como un mero elemento de conjuntos sino como de suyo. Pero no un de suyo que aspire a la autarquía, a ser de sí, en sí y para sí (como lo propone la dialéctica occidental, que, no lo olvidemos, no es cristiana, aunque la haya aceptado pacíficamente la cristiandad), sino que de tal modo se afirme a sí mismo que, en su autoafirmación, afirme conjuntamente a los demás seres humanos. Así pues, quien se define por su querencia no permite que su individualidad se desarrolle plenamente y que se asuma como tal individualidad, ni tampoco que afirme a todos los seres humanos y no solo a los suyos.

Así pues, la pertenencia parece muy deseable, incluso, para la mayoría, un camino imprescindible; pero no puede llegar a totalizar ni a los sujetos ni a los conjuntos humanos, porque la persona se constituye por la incondicionalidad, tanto de la autoposición, como de la afirmación de todos los seres humanos, vividas como dos aspectos irrenunciables de una única realidad indivisa. Dicho en otros términos, dejarse afectar por la responsabilidad que provoca el rostro del otro y ejercerla desde lo más genuino de uno es lo único que saca al individuo o al miembro de un grupo de sí y de su grupo, y lo constituye en persona.

Esta primera tensión entre arraigo y pertenencia a una tierra y a una comunidad humana, y trascendencia personal, que incluye la relación constituyente con los otros, en el sentido preciso de los distintos, relación que no admite exclusiones, lleva consigo una movilidad: del nosotros ancestral al en sí trascendente, y lleva también de la afirmación del nosotros y el yo, a la afirmación incondicional de los otros, de los que no pertenecen a mi conjunto, para lo que es imprescindible salir de sí, tanto del propio yo como del nosotros establecido. 


\section{El objetivo de las culturas las trasciende a todas}

Si concretamos esta tensión historizándola, la dialectizamos mucho más porque, si es verdad que las culturas son los modos de habérselas con la realidad (contenido) que tienen las colectividades humanas (sujeto) para constituirse en humanas (objetivo), hay que reconocer que el objetivo, que es la humanidad cualitativa, no sobre todo, en el sentido de cualificada, sino en el sentido preciso de adquirir calidad humana, trasciende a todas las culturas que han existido y existen y que existirán.

La razón es que hasta hoy no ha habido ninguna cultura que no haya incluido como principios estructuradores la jerarquización vertical y la exclusión de los otros, de los diferentes; y no cabe humanidad, en el sentido de calidad humana, sino en relaciones horizontales y mutuas y positivamente abiertas a los otros, no solo a los otros miembros del propio conjunto sino a los que no pertenecen a él, que son tendencialmente todos.

Así pues, si por un lado no cabe la humanidad acultural (Robinson es no solo imposible, sino inconcebible), por otro, no cabe sacralizar las culturas como están estructuradas y funcionan, es decir, aceptarlas absolutamente, porque ello implicaría renunciar al objetivo de constituirnos en humanos. Por tanto, no cabe más que transformar incesantemente desde dentro las culturas. Para que esta tarea sea imaginable y posible ayuda muchísimo el diálogo intercultural e incluso la interculturalidad dentro de los individuos; para lo cual hay que salir de la propia cultura y admitir en la nuestra a otros de otras culturas. Lo que incluye inexorablemente el fenómeno de la movilidad humana.

El objetivo de muchos migrantes, más allá de superar las negatividades de su lugar, es hacerse a sí mismos como seres humanos cualitativos

Esto es lo que ha sucedido en nuestra América. La mayoría de los que migraron a las grandes ciudades, lo hicieron, sin duda, porque en sus comunidades no había medios de vida, es decir, trabajo cualificado y bien remunerado, ni tierra disponible para cultivar, ni servicios mínimos a la altura del tiempo. Pero, más todavía, dejaron su terruño porque ese modo de vivir, a pesar de muchas cosas bellas y entrañables, se les había quedado chiquito: su individualidad en pleno desarrollo no cabía en él, la conciencia de su dignidad no aceptaba tanta asimetría y además tan infecunda, en las relaciones. Por eso salieron a buscarse a sí mismos para llegar a ser lo que en su pueblo nunca podrían llegar a ser.

Este impulso no era egoísta ya que desarrollo de la individualidad no equivale de ningún modo a individualismo. Y la prueba más clara de que, en grandes números, no lo hubo es que el clima de los barrios, a diferencia del de la ciudad, es la convivialidad, el vivir abiertos unos a otros en respectividad, en principio, positiva. 


\section{Jesús de Nazaret: de la "sagrada familia" a constituir la única familia de las hijas e hijos de Dios}

Como se ve, partiendo de la tendencia a la querencia, hemos llegado a la extrema conveniencia de la movilidad humana. Este corrimiento se dio paradigmáticamente en Jesús de Nazaret, que pasó del arraigo en Nazaret, tan perceptible en su Evangelio que es impensable sin ese sustrato campesino, sin el imaginario, las valoraciones y la cosmovisión que fueron cuajando en esos años lentísimos y fecundos, $\mathrm{y} \tan$ perceptible en su persona que por eso fue llamado nazareno, a llevar una existencia itinerante para comunicar a cada persona y cada grupo humano la buena nueva de la cercanía incondicional de Dios como gracia salvadora.

Y pasó de vivir en su familia como en un pedacito de cielo, a dejarla para fundar la única familia de las hijas e hijos de Dios que, en su voluntad comprende a todos los seres humanos. Si ni la familia de Nazaret pudo absolutizarse, si también ella fue invitada por Jesús a pasarse a la única familia de las hijas e hijos de Dios, ninguna cultura ni institución puede considerarse sagrada, todas deben abrirse a todos los seres humanos.

\section{La encarnación del Hijo de Dios acontece en la humanidad específica de un galileo de la primera mitad del siglo I, pero se abre internamente a todos los seres humanos en cuanto humanos por definirse como el Hijo de Dios}

Esto lo podemos teorizar de otra manera diciendo que la encarnación del Hijo de Dios fue indudablemente en una familia, en una tierra y en un pueblo concretos, como lo fue también en un tiempo determinado y esas determinaciones lo constituyeron en el ser humano concreto que fue. Pero todas esas características, siendo tan entrañables para él, no lo definieron. Él se definió como Hijo de Dios, de tal manera que esa referencia fundante remodeló todas las otras para hacerlas buenas conductoras de ella, porque ella entrañaba que se constituyera en el Hermano universal.

Esto aparece bien descrito en el Evangelio de la infancia donde, ante el reproche de su madre por haberse quedado en Jerusalén sin decírselo a ellos, de tal modo que su padre y ella lo habían estado buscando llenos de angustia, responde: ¿por qué me buscaban? ¿No sabían que tenía que estar en las cosas de mi padre? El evangelista añade que ellos no entendieron nada. Y a renglón seguido continúa diciendo que bajó con ellos a Nazaret donde les estuvo sujeto. Como se ve, una obediencia no anula a la otra, pero la obediencia a su Padre del cielo tiene la primacía sobre la obediencia a los padres de la tierra. Porque no son dos magnitudes heterogéneas ya que fue hijo de sus padres por ser el Hijo eterno de Dios, por eso esa filiación sobredetermina a la otra.

Por eso también acabará dejando a su familia para entregarse a la misión de reunir en una familia a los hijos de Dios que estaban dispersos; pero invitó a su 
familia a integrarse a esa familia escatológica y lo hizo con tal eficacia que su madre estuvo al pie de la cruz en el momento más decisivo de la vida de su Hijo y entonces él la constituyó madre de los discípulos y por eso estuvo con la comunidad que se preparaba a recibir al Espíritu para iniciar la misión. Y un hermano suyo fue uno de aquellos a los que se apareció resucitado y fue el dirigente de la Iglesia de Jerusalén y otro, Judas, escribió una de las cartas que recoge el Nuevo Testamento.

Lo mismo que decimos de la familia podemos decir de su pueblo: el que comienza diciendo que solo ha venido para las ovejas descarriadas de Israel, se abre, sin embargo, a la súplica de la mujer sirofenicia, que le hace ver que su misión, conservando la referencia paradigmática a Israel, también los incluye a ellos.

Ese mismo desborde de los moldes de su cultura lo podemos ver en el trato con las mujeres. De tal manera desborda lo ambiental que, como en el caso de la sirofenicia, en Betania acepta a una mujer que se ha puesto de discípula, y al cabo serán las discípulas las que lo seguirán hasta el fin porque, a diferencia de los discípulos, aceptan la propuesta jesuánica de servir.

Más radical es su posición respecto del templo. Se supone que cumpliría con él como todo israelita piadoso; pero el templo no aparece en su propuesta escatológica y por eso se puede poner en su boca que de ahora en adelante no se adorará en templos. De tal manera quedará superado que la acción que precipita su muerte es su destrucción simbólica porque al no permitir que se cambiara moneda ni que se trasportaran animales, privaba al templo de su función de presentar a Dios las of rendas y los sacrificios.

Lo resumimos diciendo que Jesús se hizo el ser humano concreto que fue, pero lo absoluto fue que se hizo ser humano, es decir, Hermano de todos por ser el Hijo único de Dios. Por eso, para quienes Jesús es el parámetro de humanidad, queda establecido que quien se atenga a su condición cultural o a su individualidad absolutizadas, no puede llegar a constituirse en ser humano cualitativo. Esto solo se logra al tener respectividad positiva con todos los seres humanos en cuanto humanos, es decir, al hacerse su hermano.

\section{El derecho de todos los seres humanos a poseer indivisamente la tierra}

Partiendo de la pertenencia de cada ser humano a una cultura hemos llegado a su afirmación absoluta como ser humano. Partamos ahora del otro polo: el derecho de todos los seres humanos a poseer indivisamente la tierra y, por tanto, a la ciudadanía cosmopolita y a la movilidad por ella. Tenemos que afirmar dos aspectos que parecen contradecirse, pero que, poco a poco, van convergiendo. El primero es que Dios ha dado la tierra a la humanidad, no a un ser humano ni a un grupo de ellos sino a la humanidad como un todo indiviso. El segundo 
es que este principio, que ha estado actuando siempre, se constituye en un polo de atracción de la historia humana que impide que se cierre en ninguna de sus realizaciones concretas, que hasta hoy siempre han sido particulares y no le han hecho justicia, aunque unos lo hayan realizado más que otros.

Esta voluntad de Dios de que los seres humanos ocupen la tierra como seres humanos, sin absolutizar ninguna otra característica, es absoluta. En épocas anteriores esto podía sonar a abstracción. Aunque nunca lo fue. Siempre hubo oportunidad de reconocerlo o rechazarlo, siempre se presentó la ocasión de compartir o de excluir o subordinar, tanto entre los miembros de un mismo grupo, como entre grupos diferentes. Pero hoy, que hemos llegado a la historia universal, es el principio más rechazado por los de arriba y más anhelado por todas las personas de buena voluntad. Hoy el binomio humanidad y tierra (en el sentido de mundo) es lo único absoluto. Definirse como ser humano y entender que la tierra es la casa de los seres humanos y, por tanto, de todos los seres humanos, es el principio más básico y además de expresar la realidad o, mejor, por eso mismo es el que nos puede salvar del desastre colectivo; pero también es el más controvertido y el más rechazado en la práctica por los que se quieren adueñar y de hecho se están adueñando de todo.

Para los cristianos tenemos que decir que este principio es voluntad primigenia y absoluta de Dios. No es el corolario de una tesis de una de las materias de la teología práctica, entendida como aplicación de la dogmática. Es un principio del que pende la afirmación o el rechazo real al Dios de Jesús. No se puede ser cristiano consecuentemente, si en la práctica no se acepta ese principio y no se vive en esa dirección vital.

Esto implica negativamente desabsolutizar la pertenencia a la propia nación y clase social y a la propia profesión y negocio, y, por tanto, no determinarse a pensar ni a obrar por los intereses de esa nación o esa clase o por los propios intereses sino por los intereses de la humanidad concreta.

Como Iglesia tenemos que ser sacramento de esta voluntad absoluta de Dios, sacramento de la unidad del género humano, como lo confesó solemnemente el Vaticano II. Luego tenemos, no solo que denunciar sistemáticamente el modo como actualmente se ejerce la propiedad, incluida la llamada propiedad intelectual, sino tenemos que desolidarizarnos realmente de ese sistema, pagando el precio que tengamos que pagar. Ya que, si esta voluntad de Dios es absoluta e incondicionada, no puede alegarse ningún motivo para ladearla, ni siquiera el de ayudar a las víctimas de este sistema. Solo se puede recibir dinero de los victimarios, si, aunque se lo reciba, se los sigue considerando así y se siguen denunciando sus prácticas desde la alianza con los pobres en su misma casa, en su mundo y cultura. 


\section{Los modos históricos de ir poseyendo la tierra tienen sentido, pero tienen que ir superándose hacia la toma de posesión de la humanidad como tal. Mientras tanto Dios privilegia a quienes no han encontrado lugar}

Tematicemos la consecuencia de la afirmación capital de que la tierra es indivisamente para la humanidad. Si la tierra es concretamente para todos en cuanto seres humanos y no en cuanto miembros de una nación o clase social o en cuanto propietarios, de aquí se deduce que cualquier modo concreto de realizar esta ocupación y posesión no puede aspirar a absolutizarse ni engendra derechos absolutos.

Grupos humanos, primero macrofamilias, luego clanes y posteriormente Estados, desde ciudades-estados, a señoríos, a los Estados nacionales modernos, han ido ocupando porciones de la tierra y convirtiéndolos en territorios humanos. Dentro de esas porciones la propiedad se ha subdividido, ordinariamente por núcleos familiares y actualmente por sociedades anónimas y propiedades personales. Pues bien, hay que insistir, a la vez, en que esa propiedad, cuando es legítimamente adquirida y poseída (no solo legalmente), engendra derechos para sus poseedores y frente a terceros; pero, no menos, en que esa propiedad no es absoluta, que el bien común prima sobre ella, tanto el bien común de esa colectividad, como el bien común de todos los seres humanos y, en particular, de los que están en extrema necesidad.

Dentro del judeocristianismo este último derecho es sagrado. Por eso en la Primera Alianza Dios se presenta como el Dios del extranjero, el huérfano y la viuda, es decir, como el protector absoluto de quienes no tenían protección legal.

Si el Dios de la alianza se define como del extranjero, el huérfano y la viuda, eso implica que la alianza no se dirige a Israel como grupo étnico sino como pueblo necesitado y desvalido. Luego, si Israel imita las prácticas de los pueblos vecinos y en su seno reproduce la opresión y exclusión, no actúa como pueblo de Dios. Esto lo reconoció Ezequías y su biznieto Josías y sus círculos y luego los que regresaron de Babilonia y escucharon, como los anteriores, el Deuteronomio (en fases distintas de su elaboración) y se abrieron a su mensaje y concluyeron con gran dolor que no habían ocupado la tierra como pueblo de Dios y, por eso, concluyeron que la Ley abarcaba solo los cinco primeros libros.

En la época sedentaria Dios es el Dios de los que no tienen querencia ni lugar legalmente reconocido, y que, por tanto, no pueden moverse con libertad y están a merced de la calidad humana de los establecidos. Esto significa que los establecidos solo ejercitan su condición cualitativamente humana cuando reconocen a los que no son de su conjunto y que, por tanto, no están amparados por la legalidad establecida. Como hemos dicho, lo que hagan con ellos no es un acto supererogatorio de altruismo sino lo que define su calidad humana, más allá de su reconocimiento social y de su autopercepción. 
Del mismo modo, en la Segunda Alianza la suerte definitiva depende de lo que hagamos o dejemos de hacer con los necesitados. Estos son los que no disponen de elementos mínimos para establecerse e incluso para mantenerse en vida: hambrientos y sedientos, desnudos y sin techo, enfermos sin atención y forasteros, es decir, emigrantes. Lo que se haga o deje de hacer con ellos, se hace o deja de hacer con el Señor Jesús. Ellos son, pues, su primer sacramento histórico, antes que los cristianos. Son su cuerpo, su carne, como dice plásticamente el papa Francisco. Son, pues, doblemente sagrados: como personas y como carne en la historia del Hijo único y eterno de Dios.

Así pues, las llamadas posteriormente obras de misericordia no son un complemento de los mandamientos para los que quieran vivir el cristianismo con más plenitud; son el mínimo indispensable, de tal modo que el que cumple los mandamientos no entra solo por eso en la vida eterna (Mc 10, 21 a ) ya que todavía le falta lo principal. La razón es muy sencilla: los mandamientos son la sabiduría para vivir humanamente esta vida (Dt 4, 5-9); pero la vida eterna no puede merecerse, solo se hereda (Mc 10, 25; Lc10, 27) porque es la participación en la misma vida de Dios en su Hijo Jesús. Pues bien, se pueden cumplir los mandamientos sin salir de sí, sin amar, o sea amando solo a los suyos, a los que los aman. Quien obra así no es hijo del Padre del cielo que ama incondicionalmente y se define por la misericordia que solo se fija en su desnuda humanidad (Lc 6, 33-36).

Si queremos constituirnos en humanos, los derechos de los pobres priman sobre los de los que tienen. Esto exige cambios estructurales en el establecimiento

Decir que Dios es protector de los pobres o que lo que se hace o deja de hacer a ellos se hace o deja de hacer al Señor Jesús, es un modo de poner en evidencia que la humanidad cualitativa, la calidad humana se juega en atender o no a quienes no poseen derechos legales sino que solo cuentan con su desnuda humanidad. Dejarnos o no interpelar por el rostro del necesitado decide si llegamos a constituirnos en humanos o si nos reducimos a individuos o meros miembros, tal vez muy exitosos, de determinados conjuntos. Dicho de otro modo, la capacidad de ir más allá de la lógica del sistema para afirmar a los seres humanos como humanos decide de nuestra calidad humana; y la capacidad del sistema de no absolutizarse y velar por los que no están dentro de sus mallas, decide de la calidad humana del sistema.

Hemos comenzado diciendo y lo repetimos ahora, que hoy se absolutiza la propiedad y, sobre todo, el capital privado, y, como no pueden existir dos absolutos, se relativiza, hasta desconocerlo absolutamente, el derecho de todas las personas a los bienes de la tierra y su derecho a circular por ella. Se alega que eso introduciría el caos; pero se silencia que la libertad de los capitales, sobre 
todo, de los especulativos nos ha llevado al caos en que nos encontramos y del que no vemos cómo salir, si no cambiamos de rumbo.

Hemos insistido que ese derecho, que afirmamos con toda decisión, es un derecho indivisible de la humanidad. Eso implica que no es un derecho de los individuos que se afirman como tales sino de los que, al afirmar su humanidad, afirman conjuntamente la de los demás sin excluir a nadie. Esto implica que no puedo ejercer mi derecho sin tener en cuenta el de los demás, no meramente el derecho que consagran las leyes de mi país, sino el derecho absoluto que tiene como ser humano, que debe ser, en todo caso, antepuesto al derecho legal.

La decisión actual de los Estados de blindarse a los migrantes y refugiados porque al estar en crisis el mundo, tienen que anteponer absolutamente sus intereses ante los de los de afuera, da la medida de la impiedad en que se basa el establecimiento que mediante promesas o amenazas o chantajes o dádivas a los gobernantes obligan a los países del tercer mundo a abrirse a sus intereses y luego se desentienden del caos que ello provoca. El caso más patético es el de África: el primer mundo es el que promueve y sostiene a las élites corruptas para saquear impunemente sus riquezas, y luego se desentiende de las desastrosas consecuencias que provoca esa política mafiosa y prepotente.

Como hemos venido insistiendo desde el comienzo, ellos quieren vivir en todo el mundo para expandir por todo él su influencia, para que fluyan así sus mercancías y sus capitales; pero niegan la responsabilidad que provoca su intervención y cierran la puerta a los que se desesperan por atravesar sus fronteras. Quieren resolver la crisis sin tocar la estructura que la produce. Se niegan a aceptar que no hay modo de salir de la crisis sin cambiar las reglas de juego a nivel mundial y sin tener en cuenta a todo el mundo, a toda la humanidad como sujeto responsable y en igualdad de condiciones, es decir, sin considerarse todos, por encima de sus particularidades, como sujetos humanos.

Tenemos que decir honradamente que no es esto lo que proponen las Iglesias ni en concreto nuestra Iglesia Latinoamericana. No es que lo niegue; pero cuando lo afirma, lo hace como declaración de principios y además lateralmente. No es esa su política concreta, aquello por lo que se juega.

Claro que hay cristianos y entre ellos pastores que sí están comprometidos en esta dirección vital. Pero la mayoría ha entrado en una onda de pietismo, de devociones desconectadas, no solo de la vida histórica sino incluso del Jesús de Nazaret de los Evangelios. La práctica religiosa vuelve a ser un ámbito estanco por lo que no hace falta interpretar los signos de los tiempos ni comprometerse en secundar la acción del Espíritu de Dios en esta historia de pecado y gracia.

Se propone una gracia barata, porque se está escarmentado de las décadas pasadas cuando seguir a Jesús de Nazaret conllevó participar de un modo u otro de su pasión. Y eso es lo que se quiere evitar a toda costa. Insisto en que hay 
minorías, entre ellas, personeros de la institución eclesiástica, o, por mejor decir, pastores auténticos, que, como insiste el papa Francisco, salen del templo y por eso huelen a oveja, porque comparten estrechamente la suerte de ellas, que, como dice Pablo, son llevadas (y ellos con ellas) al matadero ( $\mathrm{Rm} 8,36)$.

\subsection{Tendencia a la propia realización: aspiración a las relaciones personali- zadoras. Del autocentramiento a la salida de sí movido por la fe}

Para comprender esta polaridad tenemos que partir de la propia ontogénesis. La criatura humana es la más desvalida de las crías de mamíferos. Por eso la crianza es tan larga. Al ser el niño un ser de necesidades que no puede procurarse la vida por sí mismo, nace absolutamente autocentrado, ocupado exclusivamente en mantenerse en vida, que entraña crecer hasta llegar a valerse por sí mismo. Por eso Dios lo dotó de un arma potentísima: la capacidad de emitir sonidos mucho más allá de lo soportable por el pabellón auditivo humano, de tal manera que, si no lo quieren atender de grado, lo tengan que hacer para que los deje en paz.

Pero si sus progenitores o sus cuidadores le tienen un amor constante que antepone todo al bien del niño, más temprano que tarde el niño repara que puede bajar la guardia porque otros seres están tan pendientes como él de satisfacer sus necesidades y pueden hacerlo con solvencia.

Además de satisfacer sus necesidades, el niño busca convertirse en centro de atención constante de los que lo rodean y también chilla para lograrlo. Si sus cuidadores quieren su bien con amor constante, estarán dispuestos a aguantar pacientemente los chillidos, cuando entienden que solo obedecen al principio de placer y a la voluntad de poder, para utilizar expresiones consagradas. Así el niño irá entendiendo que él no está solo en el mundo ni es el centro de todo sino que tiene que permitir que ellos también satisfagan sus necesidades y estén entre ellos como le hacen compañía a él e incluso que él forma parte de un conjunto policéntrico.

El amor constante, esa relación personalizadora de otros con él, puede provocar en él el deseo de esa misma relación, que puede llegar y llega hasta la fe en ellos, es decir, a fiarse en que su amor por él arropa su vida y él puede llegar a descansar en ese amor y pedir ya sin angustia y aceptar compartir y hasta llegar a dar de sí.

Esto que sucede en nuestra etapa constituyente es el esquema de posibilidades de toda nuestra vida. Nunca dejamos atrás nuestra animalidad, ni, por ende, nuestras pulsiones que reclaman satisfacerse, ni tampoco nuestros deseos y sueños ni nuestro amor propio. Todo esto siempre buscará satisfacerse perentoriamente. Sin embargo, también puede elaborarse culturalmente, y así la satisfacción del hambre se llevará a cabo mediante la cultura culinaria, y la necesidad de cobijo, mediante la casa, y el instinto gregario mediante la sociabilidad, y la pulsión 
sexual mediante la familia. Todo eso lleva un trabajo, que supone postergar la inmediatez para dar lugar a la elaboración.

Esta elaboración puede ser meramente técnica o puede ser llevada a un plano cualitativamente humano. Pongamos un ejemplo paradigmático.

\section{El banquete, afirmación simbólica de la satisfacción que da el estable- cimiento piramidal o símbolo escatológico de la convivialidad de todos en cuanto humanos}

En toda la cuenca del Mediterráneo, desde tiempo inmemorial, el banquete, la mesa compartida, es símbolo de alianza en todos sus armónicos. Es decir, la satisfacción de esa necesidad tan elemental queda realizada y trascendida por el obsequio de los alimentos como señal de amistad y por el gusto de la compañía, más gratificante aún que el sabor de los alimentos, aunque todo forme parte de un conjunto complejo y humanizador.

Sin embargo, todavía no está dicho todo, porque el banquete puede ser símbolo de una alianza cerrada, que consagra un privilegio o, incluso, un conchabamiento para delinquir o de una alianza abierta en principio a todos, en la que los que participan los representan de algún modo. En una sociedad piramidal, el banquete puede convertirse en símbolo de exclusión o en el sacramento de la comunión universal, a contracorriente con el esquema dominante.

Por eso Jesús celebró banquetes multitudinarios en lugares públicos, abiertos en principio a todos, en los que, aunque comieron alimentos simples, hubo abundancia y hasta sobró, y se habló de cosas sumamente esperanzadoras y hubo alegría, y la gente no tuvo que hacer cola, como acostumbran los que dan al pueblo sin sentirse parte de él, sino que la gente se sentó en corros y se les repartió la comida como a personas dignas y respetables, y todos salieron de sí y se encontraron humanizadoramente. Y soñaron en que otro mundo es posible y hasta lo atisbaron en ese sacramento. Banquetes extrasistémicos, en los que participan los que salieron fuera de la ciudad, porque en ella solo caben los que "son" dentro de ese esquema, y en el proyecto de Dios que nos reveló y puso en movimiento Jesús los que "son" son todos los seres humanos en cuanto humanos, sin excluir siquiera a los que excluyen.

Desde la realización de esos símbolos espléndidos en los que reinaba la alegría en un horizonte de esperanza, le dijo Jesús a uno que lo había invitado a su casa y con él a otros de su entorno, que cuando diera un banquete no invitara a sus amigos y a los de su rango porque ellos lo invitarán a su vez y ahí quedará todo. Le pidió que invitara más bien a los pobres, que no podrían retribuirlo, porque entonces sería Dios mismo el que se lo iba a retribuir. Jesús lo invitaba a moverse más allá de lo establecido en lo que cabía satisfacción, pero no gracia; lo invitaba a soñar con un mundo sin discriminados en el que todos pudieran 
mirarse a la cara sin desprecio ni vergüenza sino con la alegría de reconocerse hermanos en la humanidad rescatada que nos alcanzó Jesús de Nazaret.

El banquete puede ser así meramente símbolo de preferencia, de categoría o símbolo de trascendencia. En este caso, en el que el que invita sale de su mundo al introducir a su casa a los que no tenían cómo celebrar banquetes y provoca así una movilidad social, el banquete es supremamente humanizador. De este modo el papa Francisco acaba de celebrar su cumpleaños invitando a su mesa a cuatro indigentes. Si el banquete fue, como esperamos con fundamento, no un sacrificio para merecer ante Dios y, menos aún, un gesto para la galería sino un símbolo verdadero celebrado cálidamente, es una afirmación espléndida de que para la humanidad cualitativa de los seguidores de Jesús de Nazaret los pobres son antes que los míos, incluso que los de la institución eclesiástica. Ellos dan la pauta y la medida.

\section{Movilidad física sin salir de sí, para poner a los otros para sí, o saliendo de sí para encontrarse los diferentes en el intercambio de dones. El caso del Occidente}

Lo mismo que hemos desglosado la polivalencia del banquete, podíamos habernos referido a la de la sociabilidad o a la de la familia. Las elaboraciones culturales para satisfacer humanamente nuestras pulsiones, deseos y amor propio pueden expresar así la sofisticación del autocentramiento individual o colectivo, o la trascendencia del individuo y el grupo hacia la afirmación de la humanidad como tal, que reluce en la afirmación de los pobres.

En el primer caso, aunque haya una movilidad física, ella no tiene otra función que salir de sí mismo, después de haberse habitado y poseído, para poner para sí lo que estaba fuera de sí. Es la dialéctica dominante en el Occidente, teorizada ideológicamente por él como movimiento de expansión civilizadora, pero en realidad imperialismo que depreda lo que no es Occidente y somete a sus habitantes. Como se ve, una movilidad humana muy sofisticada, con muchos medios de todo tipo, pero no para salir de sí sino para expandirse a sí mismo, para convertir todo lo que estaba fuera de sí en su zona de influencia.

Sin embargo, nunca ha faltado en Occidente una minoría muy cualificada que ha salido genuinamente de sí, que ha querido encontrarse con los diferentes, en la casa de ellos, en su cultura, no para mediatizarlos sino para reconocerlos y entablar con ellos un esquema de relacionamiento basado en la reciprocidad de dones. Al reconocerse como humanos, han podido ver la diferencia como riqueza para ambos.

\section{El caso de nuestra América: dos horizontes contradictorios y un reconoci- miento pendiente}

En la disputa que tuvieron Sepúlveda y Las Casas entre 1551 y 1552 relucen ambas posturas. Sepúlveda piensa que son los indígenas los que han salido 
ganando del encuentro con Occidente, porque a cambio del oro y la plata, que, según él, estiman poco, han recibido todos los bienes civilizatorios y culturales del Occidente y entre ellos, el más precioso de todos, el cristianismo. El dominio español en América significó, según él, un paso decisivo en la superación de la barbarie nativa con la adquisición de la civilidad cristiana. Hay que decir que esta posición la comparte la institución eclesiástica criolla, es decir, iberoamericana, cuando se define como tal, así como la mayoría de los occidentales americanos.

Las Casas reprocha a Sepúlveda que no ve a los indígenas desde sus culturas sino desde el paradigma occidental absolutizado. Y por eso ve (como lo había visto Colón al comenzar) lo que no son ni tienen, no lo que son. No lo ve porque, al venir a dominar, los españoles solo podían ver a dominados. Y para dominarlos con buena conciencia, se los tenía que inferiorizar. Se los vio además condenados por idólatras sin tener ojos para ver que ellos no eran realmente cristianos ya que adoraban al dios oro, y no puede adorarse a dos señores.

Las Casas propuso desde los primeros intentos de evangelización pacífica, un intercambio de dones civilizatorios, culturales y espirituales, pero en la casa de los indígenas, permaneciendo ellos como dueños y permitiendo que los recién llegados adquiriesen también propiedades en un proceso de mestizaje integral. Y la base de esta propuesta es el horizonte cristiano: si el Evangelio es para todos, Dios ha hecho a todos capaces de entenderlo y recibirlo; luego no son bárbaros, luego no se los puede someter, luego tienen dominio legítimo sobre sus tierras, luego solo se puede entrar a ellas llamado a su puerta y siendo recibidos por ellos. Que fue lo que no se hizo. Por eso piensa que para obtener legitimidad hay que hacer una sanatio in radice. Él piensa, fundadamente, que los indígenas estarían dispuestos a hacer su parte. Cree, fundadamente, que el problema son los españoles.

Como se ve, desde el comienzo en nuestra América la movilidad humana que da origen a América Latina se concibe desde dos horizontes contradictorios. Desde el dominante, la movilidad era meramente geográfica; no había ninguna movilidad en cuanto al contenido., ya que ellos venían a fundar la Nueva España (y también la Nueva Granada, la Nueva Galicia, la Nueva Andalucía...). Desde el de los que Puebla considera fundadores de la Iglesia latinoamericana, se trata, por el contrario, de fundar una nueva cristiandad, basada en la fraternidad entre indígenas y españoles, nacida de haber recibido todos el mismo bautismo y tener todos al mismo Dios y Padre. Como los hermanos son distintos, aunque de igual dignidad, esa fraternidad da lugar a una realidad humana inédita. En este esquema, todos salen de sí, todos cambian. Y hay lugar para todos, respetando su diferencia, aunque mediándola en una reciprocidad de dones.

Siempre ha habido cristianos en América Latina que han vivido dentro de este esquema; pero institucionalmente, después de la muerte de los fundadores, se aceptó el primer esquema y, en el mejor de los casos, se luchó por paliar sus consecuencias más negativas. La consecuencia de haber aceptado esta postura 
para la Iglesia a nivel institucional es la externidad de la institución eclesiástica respecto del pueblo latinoamericano. En el mejor de los casos lo sirvió, pero no lo reconoció como sujeto. En la institución eclesiástica caben personas de todas las etnias (aunque obviamente predominen las de etnia occidental), pero todas pertenecen a la cultura occidental. Hay gente de origen indígena o afrolatinoamericano o campesino o suburbano; pero el seminario obra como un blanqueo cultural ya que la clerecía es una subcultura de la cultura occidental americana.

Al no ser reconocidos como sujetos, como siempre hubo indígenas y posteriormente gente de culturas populares que asumió el cristianismo personalmente, lo expresan en el catolicismo popular, que no es la piedad popular, como se empeñan en minimizar algunos episcopados, sino, como lo reconoció Puebla, una religión cristiana completa en comunión católica que integra a la institución eclesiástica dentro de su esquema. Mientras no haya curas y obispos de culturas populares, debe continuar este dualismo estructural, que expresa el pecado institucional de la institución eclesiástica latinoamericana, pero que permite que ellos puedan vivir su cristianismo como sujetos.

\section{La inserción inculturada que propició Medellín y Puebla, ejemplo de movi- lidad humana trascendente y fecunda}

En principio la inserción inculturada en medios populares que propició Medellín y relanzó Puebla iba en la dirección de constituir estas Iglesias populares o, en términos de Juan XIII, Iglesia de los pobres, en la que los pobres sean, pues, sujetos y no solo destinatarios o colaboradores. Pero, como se sabe, el proceso fue abortado por los que no podían concebir un catolicismo que no fuera occidental, ignorando culpablemente que Jesús fue asiático y que católico significa universal. Gracias a Dios, el papa Francisco en su primera declaración de prensa expresó su encendido deseo de que la Iglesia llegara a ser Iglesia de los pobres y no ha parado de decir que la institución eclesiástica tiene que salir de los templos y más generalmente de la institución para buscar a los que no han logrado entrar en el sistema y viven en las periferias.

Como se ve, la exigencia cristiana es la movilidad humana opuesta a la de los migrantes: dirigirse a sus lugares de origen (a los pueblos campesinos abandonados y a las periferias de las ciudades) para que no tengan la necesidad de salir. Es decir, volver adonde fuimos desde la recepción latinoamericana del concilio, llevados por el impulso, santo y seña del concilio, de la encarnación en el mundo para salvarlo desde dentro y, más específicamente, desde la encarnación kenótica, para salvarlo, siguiendo a Jesús de Nazaret y a su Espíritu, desde dentro y desde abajo. Solo así nos salvaremos nosotros.

Desde este primer movimiento, tiene perfecto sentido ir también adonde han ido a parar en los países donde han migrado, ordinariamente lugares invisibilizados. Entramos así en el corazón de nuestro tema, que lo enunciaremos a modo de tesis. 


\section{La falta de movilidad estructural obliga a la movilidad de los que no tienen lugar. La pastoral con ellos no puede olvidar la lucha por la movilidad estructural}

Gran parte de la movilidad humana, tal como se da hoy, en el sentido de salir de su lugar de origen y emigrar a otro lugar e incluso a otro país, se debe a la falta de movilidad estructural, en el doble sentido de dificultad de ascender de nivel social y, sobre todo, de negativa a hacer los cambios en las relaciones de producción y las relaciones sociales que posibilitarían una vida digna para todos. Entonces la movilidad sería solo positiva: deseo de enfrentar nuevos retos y de encontrarse con culturas diferentes y personas distintas, aunque de igual dignidad.

Desde esta perspectiva, que es la perspectiva integral que hace justicia a la realidad, hay dos tipos de pastoral con migrantes: la que se desentiende y, por tanto, tácitamente convalida la situación que produce emigrantes y se restringe a ayudarlos; y la que, consciente de la realidad estructural de la migración, trabaja a dos frentes: tratando de transformar la situación que los produce y ayudando a los que ya han tenido que emigrar. Es claro que esta última es la pastoral cónsona con el cristianismo, que no se reduce de ningún modo a asistencialismo sino que busca superar la situación de pecado, no solo a paliar sus consecuencias.

Y, sin embargo, no es eso lo que se hace. Se hizo en Medellín y Puebla, y la Iglesia que estaba detrás de esos documentos los fue realizando sistemáticamente en sus diócesis y parroquias y en sus organizaciones. Pero, subrayémoslo de nuevo, el costo fue terrible; nada menos que la participación en la pasión de Jesús y en la de su sufrido pueblo, como gustaba decir monseñor Romero. Para estos modernos Padres de la Iglesia Latinoamericana, que empataron con los fundadores, era obvio que seguir a Jesús en una situación de pecado exigía desolidarizarse de ella: cambiar de solidaridades. Era, nada menos, que deshacer una junta que se había anudado desde que, al romper tácitamente con la línea de los Fundadores, se transó con el orden establecido. Por eso este reaccionó con todo su peso letal.

Hoy creemos que, fuera de minorías que tratan de hacer en esta situación nueva el equivalente de lo que ellos hicieron en la suya, la mayoría ha restablecido de hecho la alianza con los de arriba. No tan estructural como antes, porque hoy hemos comenzado una época en la que no se trasmite ambientalmente el cristianismo y por eso la institución eclesiástica no es tan necesaria como antaño para preservar el consenso social, pero sí se da nuevamente la pertenencia de la institución eclesiástica al estatus. Por eso en el caso que tratamos de la pastoral de la movilidad social, tan sintomático, la política eclesiástica, tácita, pero consistente, es silenciar lo que provoca esas migraciones, es decir, nombrarlo solo protocolarmente, pero no tenerlo en cuenta sistemáticamente y restringirse a ayudar a los migrantes. 
No nos hacemos ilusiones de que esto vaya a cambiar, pero creemos indispensable señalar esta infidelidad de fondo. Para no sentirla, hemos venido insistiendo, se apoya entusiásticamente el pietismo: la devoción desvinculada, tanto de las fuentes evangélicas, como de la vida, de la realidad, que es histórica.

\subsection{Prevalencia de las relaciones personalizadoras en las fuentes cristianas y movilidad humana que provoca}

Esta prevalencia de las relaciones personalizadoras sobre la autorrealización en cualquiera de las dimensiones señaladas y hasta en todas ellas, queda muy subrayada, incluso trascendida, desde la revelación judeocristiana. Veámoslo someramente.

La historia paradigmática de Abraham: de la desposesión, a la promesa de la posesión, a vivir en la movilidad sin asideros que es la relación personalizadota

La revelación histórica judeocristiana se inicia con el mandato de Dios a Abraham para que salga de su tierra y se dirija a la tierra que le mostrará y que le dará en herencia, con la promesa de que en su descendencia serán benditas todas las naciones de la tierra, es decir, con un horizonte de fondo de universalidad simbiótica. Cuando se afianzaba el neolítico y por un aumento exponencial en la productividad, cobraban auge las ciudades como posibilidad de vida para muchísima gente y por eso de división de trabajo, de complejificación de la existencia personal y social, y cuando esto sucedía precisamente en Mesopotamia, Dios pide a un ciudadano de una de ellas, de Ur de Caldea, que salga de ese ámbito estable y progresivo, aunque jerarquizado, y se ponga en movimiento.

Su destino es la tierra que él le mostrará. Él no sabe cuál. Por eso sale de ese ámbito cualitativo y se echa al desierto, una tierra no susceptible de civilización en el sentido que iba configurándose en su tiempo histórico. Parecería que desanda el camino que recorrió la historia. El suyo parece un camino hacia la nada. De la producción social de la vida, como la cota de perfectibilidad a la que estaba llegando la humanidad, a una vida dependiente de una tierra inhóspita. ¿No es una empresa insensata, como si fuera un suicidio?

A Abraham se le representaría todo esto, no desglosado, pero sí como sensación global. Pero se pone en camino porque se fía de la palabra de Dios. Su norte no es una intuición genial sino esa promesa de Dios en la que cree. Dejó la querencia, si es que la tuvo, para vivir, no en una casa ni en un país, sino en una relación. Y además no en una relación tangible, con otro ser humano, sino en una relación inasible, en libertad mutua absoluta, una relación trascendente, como lo es cualquier relación auténticamente humana, pero mucho más porque el que la inició no tiene rostro, solo la palabra inasible y ni siquiera una palabra humana sino un modo de hablar sin palabras audibles por cualquiera, pero palabras que se 
asientan en el corazón ineludiblemente. Abraham se puso a vivir en una relación de la que no podía disponer.

Desde ese momento su vida estará caracterizada por la movilidad. Mirado superficialmente, era la movilidad de cualquier nómada, una existencia histórica bien reconocible, precisamente, subrayémoslo de nuevo, la que iba siendo superada por la existencia citadina, de ciudades como Ur, de la que él salió siguiendo la guía de Dios, su mandato, su propuesta y, más a fondo su elección como dialogante estable.

También desde una mirada convencional, no sería la relación la morada de Abraham. Parecería que en la relación que propone, Dios quedaría reducido a dador de los bienes que colman al ser humano, que llegan a constituir su querencia. Tal vez en el inicio de la relación podría sospecharse de esta ambivalencia, que disminuiría mucho la densidad de la relación.

Pero, siguiendo el hilo de la historia, se percibe claramente que no es así. La movilidad de una tierra en otra, siendo forastero en todas, aunque entablando en todas relaciones simbióticas, es el signo de otra movilidad muchísimo más profunda: la movilidad de no definirse por los dones que el Señor le daba y los que le prometió sino por la propia relación personal con él. El que Dios le diera unos dones, sobre todo, la riqueza y la estima de los demás, y le postergara otros, la descendencia y, sobre todo, la tierra, ya que murió sin poseerla, lo fue llevando a comprender, a apreciar y, en definitiva, a definirse por la relación con Dios.

Este paso no se realizó sin dolor. El punto límite, el que lo acabó configurando como creyente, tuvo que ver con el hijo. El anuncio de que ya era llegado el momento de tenerlo llegó precisamente cuando su esposa y él eran viejos y habían dejado de tener relaciones, además de que ella era estéril. Como dice hermosamente Pablo, "no vaciló su fe, aun considerando su cuerpo decrépito, ya que tenía cien años, y el seno decrépito de Sara. No dudó con desconfianza de la promesa de Dios, sino que, robustecido por la fe, glorificó a Dios, convencido de que podía cumplir lo prometido" ( $\mathrm{Rm} 4$, 19-21). La fe en Dios, esa relación supremamente personalizadora, lo hizo ir más allá de sus posibilidades.

El momento supremo se dio cuando el hijo de la promesa era ya adolescente: él entendió que Dios se lo pedía como ofrenda. Él fue con el hijo al monte que Dios le había indicado y se dispuso a ofrecerlo en sacrificio. Dios entendió que para Abraham la relación con él era absoluta. Como dice la carta a los Hebreos, "pensó que Dios tiene poder para resucitar de la muerte. Y así lo recobró como un símbolo", el símbolo de lo absoluto de esta relación.

Tan absoluta fue para Dios y no solo para Abraham esta relación que el único argumento que dio Jesús para probar que los muertos resucitan es que "Dios es el Dios de Abraham" (Mc 12, 26). Como se ve, no es ningún argumento sobre la constitución del ser humano (por ejemplo, la inmortalidad del alma, que asentó 
Platón); se basa únicamente en lo absoluto para Dios de esa relación: cuando Abraham muere, Dios no se resigna a dejarse de relacionar con él y lo recrea, pero ya no en este mundo sino en su seno.

Como se echa de ver, la relación no solo puede llegar a definir a los seres humanos sino que lo define a Dios. Es por eso que la relación con él puede llegar a definir a los seres humanos: Dios es el que inicia, apoya, solidifica y consuma la relación. Por eso se puede vivir en ella y de ella.

Abraham llegó a ser así el amigo de Dios y el padre de los creyentes. Esa relación lo colmó y lo llevó a relativizar sus posesiones y hasta la promesa de la tierra, que al principio parecía el objetivo final. La querencia queda no solo completamente relativizada sino superada, trascendida. Vivir en la relación entraña la movilidad absoluta. Es la realización más extrema de que "no solo de pan vive el ser humano sino de toda palabra que sale de la boca de Dios" (Mt 4, 4). Al vivir de esta relación, movilidad suma, no hay ningún piso, el ser humano queda definido, no por su lugar de origen ni por el que él ha sido capaz de edificar, sino como hijo de Dios.

Este inicio de la historia sagrada, que marca su dirección y sentido, hace ver que no podemos mirar solo ni principalmente a la movilidad humana como un problema que debe llegar a ser superado. Es antes que eso e incluso, como hemos insistido, en medio de esta negatividad atroz, que no puede ser banalizada, una oportunidad de dejar atrás las querencias para definirse por las relaciones humanizadoras. Esa será la casa definitiva de los seres humanos, a la que hay que dirigirse desde ya, practicándolas.

\section{Al absolutizar las relaciones personalizadoras, Jesús no tuvo donde reclinar la cabeza. Seguirlo es vivir con él en el camino}

Jesús es presentado como el hijo de la promesa (Gal 3, 16). Por eso su misión no consistió en la restauración del pueblo de Dios en su tierra (la llegada por fin a la querencia como verdadero pueblo de Dios) y de este modo el cumplimiento de las promesas, unas promesas que serían, entonces, tan limitadas como lo es cualquier pedazo de tierra, aunque lo haya entregado Dios y mane leche y miel.

Hay que decir, sin embargo, que, sometidos al yugo romano y estando el templo en manos de sacerdotes venales que no se distinguían por su fervor religioso ni, menos aún, por vivir de fe, muchos, entre ellos los apóstoles, pensaban como la máxima realización de Dios con su pueblo, que Jesús llevaría adelante, en la victoria sobre los romanos y la instauración, por fin, de la alianza no solo en toda su pureza sino, sobre todo, en toda su plenitud. Por eso Jesús se sintió progresivamente solo entre sus íntimos, incapaz de lograr que salieran de su horizonte y se pasaran al que él estaba instaurando con sus palabras y obras y, más radicalmente aún, con su misma presencia. 
El cumplimiento de las promesas consistió para Jesús, por el contrario, en escatologizar la relación: al hacerse él, el Hijo único de Dios, nuestro Hermano, nos incorporó a sus relaciones intradivinas, a su filiación. En eso consistió el reinado de Dios, forma histórica de presentarse su Reino. Por eso, el que se levantó en el último grado de la instalación, ya que, aunque pobre, tenía familia, casa y oficio, al entregarse a la misión, dejó todo y ya no tuvo dónde reclinar la cabeza.

A quien en un acto inusitado de generosidad se ofreció a seguirlo adonde quiera que fuera, Jesús le respondió que no tenía ningún sitio donde ir (Lc 9, 57-58). De este modo le señalaba que seguirlo era vivir en el camino. ¿Es posible vivir no solo en camino sino en el camino? ¿Es humanizador vivir así, sin ninguna estabilidad ni pertenencia?

Podemos admitir que definirse por una querencia es reducirse ya que cualquier querencia es menos que uno, pero, si ese extremo deshumaniza ¿no deshumaniza igualmente esa carencia de anclaje, de referencias fundantes? Un ser así, ¿no es proclive a mostrarse tan desapegado que suena a despiadado? ¿Es de fiar una persona así, que no se sabe por dónde va a salir? ¿No será capaz de cualquier cosa? ¿Se puede entablar trato con él? ¿Desde qué referencias?

Estos temores serían fundados si aquel a quien se le atribuyen esas sospechas fuera un individuo. Pero un ser así no tiene nada que ver con Jesús de Nazaret. Estamos insistiendo, por el contrario, que Jesús se definió por sus relaciones, tanto que ellas lo constituyeron en nuestro Hermano, como era ya y por serlo, Hijo de Dios.

Así pues, seguirlo es ser compañero suyo, vivir en relación con él y desde esa relación, formando parte de ella, vivir de la relación con Dios como hijo suyo verdadero en su Hijo único, y vivir de la relación con las hermanas y hermanos que iban naciendo, que eran los que aceptaban la propuesta de Jesús. Se podían rebasar las identidades de origen y de función (de tal pueblo, de tal familia, de tal oficio) porque se vivía en esas identidades propiamente humanas, relacionales: hijo de Dios y hermano de los demás, en Jesús, el Hijo único y el Hermano universal. Esta identidad relacional no niega las identidades anteriores, pero sí las relativiza y las abre para que trascendiéndose desde dentro puedan ser portadoras de estas relaciones escatológicas.

Por vivir en esas identidades relacionales, Jesús, a pesar de que en adelante vivió del hospedaje de los demás, no vivió en la ansiedad constante de no saber si le iban a dar comida y si dormiría bajo techo. Vivió en paz porque sabía que su Padre velaba por él. Esto no significaba, ante todo, que esos problemas diarios y tan acuciantes iban a quedar siempre resueltos, como mágicamente, por la acción directa de su Padre. 
Significaba, en primer lugar, que lo que le tocara pasar no lo pasaría solo sino con su Padre, y él confiaba que se podía vivir de esa relación absoluta e incondicional. Como el Amor es el comienzo de la vida, el amor constante de su Padre que le hacía ser lo que era, le daría, en todo caso, ánimo para vivir lo que le tocara, por más adverso que fuera. Él vivía de esa fe, de esa relación supremamente personalizadora.

Pero en todo caso Jesús era, como nosotros, un ser de necesidades. Si por ser Hijo de Dios, su Padre no metía la mano en el mundo directamente para satisfacerlas, ¿cómo lo hacía? La providencia de Dios no actuaba directamente sino mediante los que aceptaban su fraternidad y en ella a su Padre como Padre de ellos. Jesús iba comunicando con sus palabras y con sus obras y, sobre todo, con su presencia el acontecimiento de que la alianza de Dios con su pueblo se estaba cumpliendo sobreabundantemente: al hacerse él nuestro hermano, su Padre se hacía nuestro Padre. Esta fraternidad se expresaba dando aliento, conciencia de la propia dignidad, desalienando, sanando, convocando al pueblo sobrecargado y disperso, como ovejas sin pastor. Las personas que recibían su don y veían que sus vidas se iluminaban, se rehacían, se plenificaban y encontraban un norte y fuerzas para caminar a él, le ofrecían su casa como un modo de expresar su alegría. Y Jesús la aceptaba con agradecimiento. Así Jesús nos enseñó que quien se pone en manos de Dios se pone en manos de quien se pone en manos de Dios.

De ese modo la relación se convierte también en fuente material de vida y de pertenencia, la pertenencia a la familia de las hijas e hijos de Dios, cuyo Hermano mayor es Jesús. La ley en ella es la reciprocidad de dones en la que cada quien da con alegría lo mejor de sí y recibe con agradecimiento los dones de los demás.

Si Jesús es el ser humano definitivo, el paradigma, pero también el prototipo y el arquetipo de humanidad y Jesús se define como Hijo único y eterno de Dios y como Hermano incondicional y universal, si se define, pues, por esas relaciones, ello implica que, aunque sea, como todos los demás, un ser humano concreto, situado en un espacio y un tiempo, en un pueblo y en una cultura, en una religión, en un oficio y una familia, no se define por esas particularidades que lo ligan a otros que las comparten y lo distinguen de los demás, sino por las relaciones trascendentes de Hijo y Hermano. Son relaciones que traspasan desde dentro todas las fronteras para alcanzar a todos los seres humanos en cuanto humanos.

Hoy, cuando estamos llegando a la historia universal porque todos estamos virtualmente en presencia de todos y porque las mercancías y los capitales están en todo el mundo y las grandes corporaciones y los grandes inversionistas y las grandes potencias se mueven por todo el mundo, imponiendo sus mercancías, su imaginario y sus reglas de juego, pero que no es todavía universal porque los seres humanos del tercer mundo y de los cuartos mundos encuentran barreras inexorables y se les niega la condición de sujetos de esta historia que, 
sin embargo, padecen, el paradigma de Jesús es a la vez el símbolo vivo más ecuménico y convocador, el que marca la única dirección posible, si la historia quiere llegar a ser humana y no naufragar, pero es también un símbolo revulsivo, inasimilable en la dirección dominante de esta figura histórica que se niega a permitir que todos los seres humanos lleguen a ser sujetos de la única historia. Jesús es así una bandera discutida.

Jesús marca el esquema trascendental de la movilidad humana, para que, asumiéndola, cese la movilidad humana del tercer mundo, tal como hoy se da: como expresión escandalosa e inocultable del pecado del mundo, y se instaure la movilidad, únicamente positiva, del deseo de ir más allá, de encuentros con los diferentes, para que, en la reciprocidad de dones, salgamos todos enriquecidos. Esta positividad se da ya como victoria que vence al pecado.

Entonces el habitar en su casa viviendo de su trabajo con su familia, siendo una meta deseable, no será ya la meta final porque se querrá ir más allá, viviendo, sobre todo, en los pronombres, no solo en el yo y tú ni en el nosotros de la familia, los amigos y los nuestros sino en el nosotros que no excluya a nadie y abarque tendencialmente a todos los seres humanos, reconocidos como hermanos en el único Dios y Padre de nuestro Señor Jesucristo, nuestro Hermano mayor, el Hermano universal.

\section{Líneas maestras de la pastoral desde el horizonte cristiano de la movi- lidad humana}

Este horizonte hace aflorar algunas líneas maestras que tendrían que configurar el telón de fondo de la pastoral.

\subsection{La pastoral con migrantes enfrenta el pecado del mundo que solo se puede vencer con la fuerza del espíritu de Jesús: la desnuda humanidad cualitativa de un hijo de Dios}

La primera línea maestra es que habría que entender el fenómeno de las migraciones del tercer al primer mundo como una situación límite, propicia para que aflore lo mejor y lo peor de las personas, tanto de los mismos migrantes, como de los que tienen trato con ellos. Esta situación límite está provocada por lo que hemos caracterizado como pecado del mundo: la asimetría extrema, la opresión y la exclusión, tanto en los lugares de origen como en los lugares de acogida, relacionados ambos por una globalización extorsionadora, lo que Medellín caracterizaba como "imperialismo internacional del dinero" y que hoy alcanza dimensiones marcadamente fetichistas, como lo calificó el papa Francisco al recibir por primera vez las cartas credenciales de cuatro embajadores.

Esta situación de pecado distorsiona tanto la realidad que, al poner a los migrantes en situaciones en las que se juegan la vida sin ninguna protección, a 
merced de organizaciones mafiosas internacionales, al vivir frecuentemente en condiciones de gran precariedad y trabajar en trabajos muchas veces desechados por los del lugar y sin estatuto jurídico, al vivir esforzándose tanto que no quedan energías ni ganas para esparcimientos sanos, al sufrir tantas contrariedades y con tan pocas satisfacciones, las personas pueden entregarse a pulsiones elementales que los reducen a bestias, o pueden optar por desvivirse hasta acumular dinero suficiente para dedicarse a vivir, sin percatarse que ese vivir ya del dinero adquirido no es humanizador y que desvivirse poniendo todas la energías en conseguir dinero se les convierte a veces en un modo de vivir del que luego no pueden desprenderse, o van subiendo poco a poco, introyectando el esquema y haciendo con otros lo que les han hecho a ellos, o pueden hacer de la necesidad virtud y aguantar con estoicismo y sacar lo mejor de sí para afrontar humanizadoramente un trance tan inhumano.

Como se ve, solo la última de las opciones es humanizadora.

La pastoral tiene que ser consciente de que esos seres humanos no solo son carenciados de muchos modos sino que están fortísimamente tentados a perder su humanidad, a hipotecar su dignidad, y que, si no sacan lo mejor de sí y se agarran a motivaciones trascendentes y no son ayudados humanamente, hay muchas probabilidades de que de un modo u otro sucumban. La pastoral, pues, no tiene que enfocarse solo a ayudar materialmente, lo que de ningún modo puede faltar, sino, sobre todo, a ayudar humanamente, y aun la ayuda material debe llevarse a cabo lo más humanizadoramente posible.

Ahora bien, en situaciones límites no basta un consejito piadoso ni una palabra bienintencionada. El migrante tiene que percibir la densidad humana de quien se relaciona con él para que la prestancia de esa fuerza irradiadora tenga poder para contrarrestar otras direcciones deshumanizadoras. Aquí no hay truco. En la cotidianidad puede enmascararse la falta de densidad humana; en situaciones límites queda en evidencia.

Lo mismo podemos decir del llamado a una experiencia religiosa. Solo quien de hecho se relaciona personalmente con Dios de manera que en una medida apreciable él sea la vida de su vida, puede poner a una persona que se encuentra en ese trance en contacto real con él. Lo mismo hay que decir de la referencia a Jesús o a María de Nazaret o a un santo.

Por eso esta pastoral también pone a prueba a los agentes pastorales, de manera que aquí vale que "al que tiene se le dará y al que no tiene, aun lo que tiene se le quitará” (Mt 25, 29). En efecto, quien, aun en medio de flaquezas y contradicciones, vive la humanidad de los hijos de Dios que nos alcanzó Jesús, al comunicarse con los migrantes desde ella, al ejercerla, se le incrementará, sin duda, porque en lo valioso solo se tiene lo que se da y precisamente se recibe al darlo; pero el que cree que la posee, pero en realidad vive solo de doctrinas y 
ritos, en contacto con la verdad de esa relación desnuda, esa capa de cristianismo se le volatiliza y se siente desnudo e impotente.

\subsection{La pastoral tiene que aceptar que los migrantes son portadores de la universalidad que el sistema niega, por tanto, ha de ejercerse desde ella y no desde la cultura que la niega}

La segunda línea maestra es que habría que entender el fenómeno de las migraciones como un principio de universalización desde abajo, a contrapelo de la negativa de la dirección dominante de esta figura histórica a que todos seamos sujetos de esta historia que ya nos abarca inexorablemente a todos. Por eso hoy las migraciones son un fenómeno altamente sintomático, tanto de la situación actual de pecado que las fuerza y las torna tan difíciles, como, más todavía, de las virtualidades de los migrantes, y, por eso último, constituyen un fenómeno de incalculable trascendencia.

\section{Los migrantes obedecen al Espíritu. La pastoral debe encaminarse a que se afiancen en esta dirección vital}

Aquí hay que hacer una afirmación trascendente: los migrantes se dejan llevar por el Espíritu, lo obedecen. No afirmamos, obviamente, que lo obedezcan en todos los niveles de su vida ni que lo obedezcan siempre. Lo que afirmamos, y es muchísimo, es que lo obedecen, sin duda, porque no teniendo elementos para vivir, viven. Esto significa que viven del Espíritu, que es Señor y dador de vida. Es Señor porque logra que vivan venciendo todos los obstáculos. Si no se echan a morir en su lugar de origen en el que ya no encuentran posibilidades para vivir y para hacerlo con dignidad, y tienen el coraje de migrar a otra tierra cuyo idioma, muchas veces, no conocen, muchísimas veces sin papeles, explotados por mafias, empleados en condiciones de inferioridad, viviendo con suma estrechez, y, sin embargo, viven y muchas veces progresan o, al menos, encuentran cómo vivir y cómo enviar remesas a su familia, si no han perdido el sentido de su dignidad y luchan porque salga a flote y hasta logran encontrar gente que los ayude y a veces hasta patronos comprensivos, si son capaces de aprender muchas cosas, si hasta tienen momentos de expansión y de alegría y hasta llegan a valorar aspectos de su cultura y cultivan la religión que les sirve de referencia trascendente, no se puede dudar que obedezcan al Espíritu. Eso no significa, repetimos, que obedezcan siempre y en todos los aspectos de su vida; ya es mucho que lo hagan en lo que hemos señalado.

Esto es parte de lo que Jon Sobrino designa como "santidad primordial" y nosotros calificamos analíticamente como "conato agónico por la vida digna". Conato es la palabra que emplea Spinoza para calificar al empeño por mantenerse en la existencia, que para él es el primero y único fundamento de la virtud, en el sentido latino de virtualidad positiva, y que es el empeño que ha presidido la expansión del Occidente y caracterizado así a su pathos y a su ethos. Pero, a 
diferencia del de Occidente, que se realiza a favor de la corriente, este empeño es agónico: una verdadera lucha por vivir cuando faltan condiciones para hacerlo porque les son negadas. Por tanto, requiere un ejercicio mucho más enérgico de subjetualidad. Creemos que este es un dato que no suele reconocerse y que para la pastoral es indispensable hacerlo.

Pero además el empeño de muchos migrantes no es meramente por conservarse en la existencia sino por avanzar en todos los niveles, no solo en el económico sino en el de capacitación, apertura a lo distinto, convivialidad, ayuda mutua, sacrifico de sí para bien de otros. Pues bien, nosotros insistimos en que esa pasión que los moviliza, no solo expresa lo mejor de sí sino que entraña una obediencia habitual al impulso del Espíritu, Señor y dador de vida. Y por eso entraña también un ethos, una exigencia trascendente que los lleva a hacer todo eso humanamente, al menos como tendencia dominante.

Si una pastoral no parte de este reconocimiento, no es una pastoral cristiana. Y reconocerlo implica secundar su impulso. La pastoral, si no quiere perder su referencia cristiana y reducirse a la labor de una ONG, no puede limitarse a ejecutar programas atenidos a aspectos específicos. Tiene que partir de este reconocimiento y de la colaboración para que esa obediencia trascendente al Espíritu sea cada día más integral. Si se da este reconocimiento, se dará un inmenso respeto y una valoración primordial.

Entonces, correspondientemente, la pastoral ayudará también a los que la ejercitan a avanzar en su obediencia al Espíritu y, consiguientemente, en su humanidad cualitativa. Esto es capital porque solo hay pastoral cristiana cuando la ayuda al necesitado ayuda también al ayudador, que se convierte así en ayudado por el necesitado de ayuda. Esto lo dijo Juan Pablo II en una frase lapidaria: "la misericordia solo es cristiana cuando el que la ejercita experimenta recibir misericordia de aquel a quien se la hace".

\section{Los migrantes son sujetos. La pastoral no puede tratarlos como destinata- rios de su acción, sino en relaciones horizontales y mutuas}

Si los migrantes obedecen al Espíritu al vivir cuando no hay condiciones para vivir, como esta obediencia no es, como hemos visto, algo mecánico sino que entraña poner incesantemente en funcionamiento los resortes más profundos, los migrantes son sujetos que toman su vida en sus manos, y como son sujetos a contrapelo, inferiorizados, invisibilizados, explotados, son, por eso mismo, mucho más sujetos, porque para constituirse en tales tienen que sortear inmensos obstáculos de muy variada índole y muchos logran hacerlo.

A los migrantes no se los puede, pues, considerar meramente como carenciados y privados injustamente. Claro que lo son, pero son ante todo sujetos. Por tanto, la relación con ellos no puede ser de donante a receptor del don; han de ser 
en todo caso relaciones de sujeto a sujeto, relaciones mutuas y horizontales en las que ambos den y reciban.

De hecho, se reconozca o no así, eso es así en la sociedad que los recibe y es cierto que en esa relación, en la que ambos dan y reciben, sale ganado el país receptor. Lo mismo tiene que suceder en la pastoral con ellos y no solo tiene que suceder de hecho sino que tiene que plantearse explícitamente.

\section{La misericordia es cristiana cuando el que la da experimenta recibirla de quien la recibe}

Los que se ocupan de los migrantes en los lugares de recepción y, más todavía, en los países de tránsito lo que perciben es una precariedad extrema, tanto que lo más elemental y perentorio es que sigan viviendo. Así tiene que ser. La necesidad extrema no puede esperar. Por eso la actitud más elemental con ellos es la misericordia.

A este respecto había que decir dos cosas, la primera y la más primaria y trascendente es que, si para los cristianos ellos son la carne de Cristo, como no se cansa de repetir el papa, no se los puede atender como a animalitos aterrorizados y en extrema necesidad e indefensión sino como a nuestros señores, puesto que atenderlos a ellos es atender al Señor Jesús.

Esto hay que tenerlo muy presente porque, de buenas a primeras lo que se percibe es la desigualdad de la relación, la condición de inferioridad de ellos y, consi-

guientemente, de superioridad del que atiende. Desde esa situación la misericordia puede degenerar en lástima y dejar de ser una relación genuinamente humana, ya que, como hemos venido insistiendo, esta solo se da entre iguales y tiene que ser mutua. Por eso, lo segundo que quisiéramos insistir es que la misericordia solo es genuina si el que la ejerce experimenta recibirla de aquel a quien se le da. Y por esto ayuda lo que acabamos de decir, que lo que se hace con ellos se lo hace a Cristo.

Nos hemos extendido en esto porque cuando los requerimientos materiales son tan abrumadores y perentorios, puede ladearse inconscientemente la calidad humana de la relación en la que se satisface esas necesidades, al absorber ellas toda la atención.

\section{Los migrantes son portadores de universalidad. Los que ejercen la pastoral tienen la oportunidad de participar de ella, si relativizan su cultura y se abren a la de ellos}

Así pues, hay que atenderlos con toda eficacia; pero simultáneamente hay que hacerlo teniendo en cuenta que son portadores de la universalidad por abajo, en el momento en que el orden establecido niega la posibilidad de constituirnos en historia universal, al negar a los pobres de los terceros y cuartos mundos la condición de sujetos. Por eso, como insiste el papa, no solo hay que ayudarlos a 
que sobrevivan sino hay que darles lugar, hay que colaborar a que lo consigan y, para eso, a que se cualifiquen y a que adensen su humanidad y a que consigan el estatus que tercamente se les niega.

Es crucial que quienes acompañan pastoralmente a los migrantes sean conscientes de que en ellos se está jugando hoy la posibilidad de la historia universal, algo querido, sin duda, por Dios y a lo que mueve sin duda su Espíritu. Es cierto que este tránsito no solo se da en ellos, pero sí pasa ciertamente por ellos.

Por eso, los que se empeñan en esta pastoral, si se dejan llevar por esas relaciones y por lo que el Espíritu suscita en ellas, ampliarán su propia identidad. No se definirán ya por su pertenencia a su cultura, porque comprenderán vitalmente sus estrecheces, al experimentar desde el lado de ellos las inmensas trabas que les ponen y el desconocimiento, el desprecio y la opresión de que son objeto. Y, por otro lado, al ser testigos de cómo reaccionan, cómo aprenden, cómo van procesando lo que viven, comprenden desde dentro las virtualidades de sus culturas de origen. Así los que acompañan a los migrantes aprenden a discernir su propia cultura y fomentan en sí mismos lo más dinámico y humanizador y se lo entregan a los que vienen, y niegan o trasforman lo que tiene de excluyente y mezquino. Que se dé en ellos este proceso será la prueba de que su pastoral es genuinamente cristiana.

Esta relativización de la propia cultura es imprescindible para que la cultura logre el objetivo de que los que viven en ella alcancen la humanidad cualitativa. La extrema dificultad de que esto suceda en las culturas dominantes estriba en que por su éxito tienden a absolutizarse confundiendo su modo de vivir en ellas con la humanidad cualitativa. Y, como hemos dicho, esto no es así ya que todas ellas contienen principios de exclusión y relaciones piramidales, que impiden el ejercicio de la humanidad cualitativa, que solo se puede dar en relaciones horizontales y mutuas. Esta relativización de la propia cultura es el gran bien que la pastoral con migrantes causa en los que la practican, si lo hacen cristianamente, es decir, abriéndose al acontecimiento de la relación, lo que posibilita y propicia que los migrantes sean percibidos no solo como necesitados sino como seres dignos y cualitativos.

Los migrantes latinoamericanos, en lo que tienen de genuino, que es mucho, actúan lo mejor de sus culturas y se abren a lo mejor de las de los países receptores. La pastoral debe ser consciente de este proceso y ayudar a potenciarlo

Es cierto que hay emigrantes que a causa de su condición cultural, que incluye un horizonte religioso, que viven como un paquete cerrado, no pueden abrirse al país receptor como tal sino solo se aprovechan de sus ventajas, manteniéndose por lo demás impermeables. Pero no sucede así con los migrantes latinoamericanos que estamos considerando. Ellos, bastantes de ellos, saben nadar y guardar la ropa, es decir, ser leales con el país donde migraron, sin por eso perder sus raíces. Muchos no solo no las pierden sino que las repristinan 
porque experimentan que muchas de ellas les posibilitan esa travesía y, lo que es todavía más valioso, no perder el alma en ella.

Este proceso de reculturización, en el doble sentido de reasumir con más profundidad la cultura propia y de asumir lo percibido como valioso en la del país receptor, debe ser tomado muy en consideración por la pastoral. Porque es otra de las manifestaciones del adensamiento del sujeto del que hemos venido hablando y contribuye en mucho a la realización del conato agónico por la vida digna, que constituye la trascendencia de estos sujetos humanos.

En efecto, el punto de partida es que la cultura, al haber sido asumida en los procesos de enculturación y endoculturación, va formado parte del ser propio de modo implícito, como algo que está ahí, constituyendo los modos de habérselas con la realidad que están a la mano. En la mayoría no se da la reflexión adulta y, menos aún, el discernimiento espiritual. Esta naturalización de la propia cultura constituye una gran limitación para el proceso de personalización. Sin embargo, al tener que arrancarse tan abruptamente de la propia cultura y experimentar tan a contrapelo a la receptora, se da, de buenas a primeras, un proceso de elementarización, que en muchos casos es vivido, sin embargo, como de asirse a las certezas y valoraciones últimas y comprobar que sí funcionan. De este modo se tiene una experiencia del propio ser cultural absolutamente personalizada. Este núcleo mínimo y denso será la base que aglutine lo que en la propia cultura sea buen conductor de él y para asumir lo que en la cultura receptora se ve compatible y potenciador y, no menos, lo que lo amplía. Este proceso es una experiencia apasionante, que ordinariamente no se da en los que viven en continuidad vital en la cultura en la que han nacido.

Por eso el agente pastoral no puede restringirse, como hemos venido insistiendo, a tareas específicas perentorias, que, sin embargo, repitámoslo una vez más, son indispensables, y debe abrirse para percibir esta elaboración tan creativa. Ayudarles a hacerse conscientes de ella y a elaborarla de la manera más adecuada posible, tiene que formar parte de esa relación mutua cualitativa y enriquecedora para ambos. Porque, insistámoslo de nuevo, es un campo en el que más puedan potenciarse mutuamente.

Los migrantes, con frecuencia, reasumen su religión en su vertiente más personalizadora. La pastoral ha de comprender ese fenómeno para ayudar a alimentarlo

Eso sucede frecuentemente con su religión, que la valoran y practican más que en su lugar de origen, porque, al encontrarse en situaciones límites, la practican en su núcleo más elemental y trascendente. Por eso la pastoral tiene que incluir el fomento de esta fuente vivificadora. No, obviamente, por proselitismo sino porque la práctica del cristianismo, en el sentido más primigenio de la relación libre y personal con el Dios de Jesús, con el propio Jesús, con su madre y con los santos, ayuda a mantenerse en vida y a vivir humanamente; dicho con 
otro registro, a discernir al Espíritu de Jesús y a seguir su impulso. Así pues, es importante que la pastoral comprenda que la fe genuina alimenta al conato agónico por la vida digna. Saber, como Codina oyó de labios de una mujer indígena pobre, que "diosito nos acompaña siempre" da fortaleza para pasar muchos tragos amargos, no solo con vida sino con dignidad y paz de fondo.

Pero para que el agente pastoral ayude y no distraiga, tiene que comprender que formulaciones como estas son expresiones cabales de la fe cristiana. Si lo comprende, sabrá que la pastoral no consiste en atiborrar de doctrinas y prácticas sino en ayudar a que esta experiencia de que Dios en Jesús es Dioscon-nosotros y para nuestra salvación se adense cada día más y en ilustrar mediante las narraciones evangélicas, cómo así aconteció en cada encuentro de Jesús con los necesitados y sigue aconteciendo siempre. Esta cercanía incondicional y saludable de Dios la simbolizan los sacramentales y la debe simbolizar también y mucho más la cena del Señor, si se celebra como Dios manda y no como un rito esotérico que tiene como sujeto al sacerdote y en el que ellos son meros destinatarios.

\section{Los migrantes tienen la oportunidad de relacionarse como seres humanos con seres humanos y demandan ser tratados como humanos. La pastoral tiene que ser consciente de esta oportunidad humanizadora $y$ debe realizarla y potenciarla}

En lo que más tiene que distinguirse la pastoral con los migrantes es en ejercitar con ellos relaciones personalizadoras de manera que, al hacerlo, puedan ayudarles a hacerse cargo de que en esa existencia tan azarosa, en la que ha habido tantos desgarrones lacerantes, tantas barreras sentidas como injustas, tanto aprovechamiento de sus personas, sin embargo, también se han dado encuentros gratuitos muy confortantes y sacrificios fecundos. Tienen que ayudarles a ver que al fin lo que les va quedando como un tesoro que no pueden robar los ladrones ni roer la polilla, es lo que se ha dado en sus vidas de salida de sí, de encuentros realmente humanos, de hábito de dar de sí, de ser útil y ocupar así con derecho y dignidad un puesto en una sociedad, que no pocas veces le niega, sin embargo, el reconocimiento, y de continuar los lazos en la distancia y aprender a ser fieles y a dar vida, aunque uno no vea el fruto y recele de los que se quedaron en el lugar de origen, y haya que vencer la tentación de echarlo todo a rodar y vivir solo en el presente y de lo que él puede dar de satisfacción.

Cuando el migrante no cuenta ya con el control ambiental del contorno de origen que ayuda a mantener la compostura, cuando vive en tierra extraña y se le empuja por todos los medios de comunicación a vivir en el individualismo y en el presentismo, no es fácil anteponer la relación personalizadora como el tesoro escondido que uno tiene que encontrar, sabiendo además que para cultivarlo hay que venderlo todo, es decir, hay que vencer la tentación de irse por las ramas, 
malgastando su tiempo, sus energías y sus recursos en satisfacciones fugaces. Entablar vínculos personalizadores y vivir en ellos parece muy frágil y no pocas veces suena a invertir a fondo perdido. Pero la alegría de esas relaciones va dando fuerza para vivir en ellas.

Para un cristiano esas relaciones trascendentes son, en definitiva, relaciones humanas, es decir, que no se confinen a un grupo humano, sea la familia, los amigos, los compañeros de aficiones o de trabajo o de partido o, más en general, la gente en la que uno encuentre complacencia. Uno llega a ser persona cuando en la afirmación absoluta que hace de sí, afirma conjuntamente a los seres humanos como humanos y no excluye, consiguientemente, a nadie. Cuando una persona sale de su país, sale de su cultura y de su entorno. Por tanto, las relaciones que entabla, fuera de relaciones estrictamente contractuales, protocolizadas, es más fácil que sean relaciones genuinamente humanas ya que no reconoce en aquellos con los que las entabla los rasgos familiares que funcionaban como lazo de unión. Es fácil que en esos casos reconozca en el otro a un ser humano.

Claro está que también puedo reconocer en mis padres y hermanos, en mi esposa y en mis amigos y compañeros a seres humanos. Pero eso solo lo podré comprobar cuando esas relaciones no se confinen a ellos y se extiendan a seres humanos que no son de esos grupos de pertenencia. Esa experiencia la puede hacer alguien al acoger a un emigrante o un emigrante al abrirse al de la cultura extraña. La experiencia está abierta a ambos, pero el del país puede alegar que no conoce a nadie fuera de su mundo-de-vida, mientras que el emigrante no puede no encontrarse con el otro. Insistimos que la tienen que hacer ambos, si quieren constituirse como personas, pero al emigrante se le presenta masivamente la oportunidad y hasta casi la necesidad de hacerlo. Casi, porque siempre caben las relaciones meramente conductuales; y por eso entablar las personalizadoras es en todo caso un acto deliberado del sujeto humano.

A este respecto hay que decir dos cosas complementarias: la primera es que el emigrante, como hemos venido insistiendo, es portador de humanidad, tanto cuando se relaciona humanamente, como por aparecer en esa cultura como el otro que solo puede ser aceptado en cuanto ser humano. Del primer modo ejerce humanidad y en el segundo la demanda. De ambos modos empuja hacia la historia efectivamente universal. Por eso hay que verlo como portador de una oportunidad histórica, de una gracia. Desperdiciarla despersonaliza. Así hay que proponer en último término esta pastoral ya que eso es lo que está en juego.

\section{Los hombres del mar}

Esto que decimos de los migrantes, lo decimos más en general de toda la pastoral de la movilidad. Es claro que un marino tiene la oportunidad de tener un horizonte más amplio que alguien que viva habitualmente en su entorno nativo. $\mathrm{Y}$ es una experiencia comprobada que muchos marinos aprovechan esta oportu- 
nidad y son más amplios y así son capaces de superar muchos prejuicios de su lugar de origen y de valorar aspectos variadísimos de otras culturas de los que los de su cultura de origen no son conscientes y no tienen interés vital en abrirse a ellos. Y de este modo llegan a hacerse cargo bastante concretamente de lo humano en sí, que aunque siempre se da culturalmente, trasciende a cada cultura.

Claro está que, complementariamente, al no sentir las cortapisas del control social de su lugar de origen, también tienen la tentación de vivir irresponsablemente. También ellos, como los migrantes, aunque no estén en la situación límite de ellos, navegan entre esas dos coordenadas de una libertad, que necesita ser liberada para actuar responsable y creativamente, y de una oportunidad excepcional de actuar el principio de universalidad de que son portadores.

\section{Conclusión}

El cristianismo sostiene que la meta humana es vivir en relaciones personalizadoras. En la escatología esas relaciones serán las de hija e hijo de Dios y hermana y hermano de todos los seres humanos. Pero esa escatología no será de ningún modo deseable ni posible si en esta historia no se han ejercitado esas relaciones definitivas. A ellas nos hemos estado refiriendo cuando hemos insistido en la necesidad de reconocer a todos como seres humanos y relacionarnos con ellos como tales. Como juicio de hecho hemos asentado que los que comandan esta figura histórica y los que se aprovechan de ella, resisten por todos medios a este reconocimiento y se afincan en sus identidades no universalizables. Las migraciones, tal como de hecho se dan, invisibilizadas y hostilizadas, se deben a esta exclusión de la movilidad humana por abajo, en un momento histórico en que el dinero y las mercancías y los de arriba se mueven sin cortapisas. Por eso ellas evidencian el pecado del mundo, que obra activamente en contra del reinado de Dios. Pero también en ellas está presente y actuante el principio de universalidad negado por los de arriba.

La pastoral de la movilidad, si quiere ser cristiana, tiene que ser consciente de lo que está en juego en ella y denunciar el pecado del mundo y actuar en contra de él, y percibir el impulso del Espíritu que actúa en los migrantes y ayudarlos a que se entreguen a él, sabiendo que para que lo hagan tienen que superar muchas tentaciones y densificar el sujeto y liberar la libertad. Correspondientemente también los agentes pastorales tienen que vencer la tentación de actuar como representantes de su cultura, aunque sea de lo mejor de ella, y abrirse a la humanidad de los migrantes desde su propia humanidad. Así se harán capaces a su vez de ver lo negativo de su cultura y superarlo y lo más dinámico y actuarlo. De este modo la pastoral será la actuación de la fraternidad de las hijas e hijos de Dios, del Dios de Jesús. 